\title{
Transport of trace gases via eddy shedding from the Asian summer monsoon anticyclone and associated impacts on ozone heating rates
}

\author{
Suvarna Fadnavis ${ }^{1}$, Chaitri Roy ${ }^{1}$, Rajib Chattopadhyay ${ }^{1}$, Christopher E. Sioris ${ }^{2}$, Alexandru Rap ${ }^{3}$, Rolf Müller ${ }^{4}$, \\ K. Ravi Kumar ${ }^{5}$, and Raghavan Krishnan ${ }^{1}$ \\ ${ }^{1}$ Indian Institute of Tropical Meteorology, Pune, India \\ ${ }^{2}$ Air Quality Research Division, Environment and Climate Change, Toronto, Canada \\ ${ }^{3}$ School of Earth and Environment, University of Leeds, Leeds, UK \\ ${ }^{4}$ Forschungszentrum Jülich GmbH, Institute of Energy and Climate Research - Stratosphere (IEK-7), Jülich, Germany \\ ${ }^{5}$ Atmospheric Sciences, Indian Institute of Technology, Delhi, India
}

Correspondence: Suvarna Fadnavis (suvarna@tropmet.res.in)

Received: 14 February 2018 - Discussion started: 12 March 2018

Revised: 31 May 2018 - Accepted: 26 June 2018 - Published: 15 August 2018

\begin{abstract}
The highly vibrant Asian summer monsoon (ASM) anticyclone plays an important role in efficient transport of Asian tropospheric air masses to the extratropical upper troposphere and lower stratosphere (UTLS). In this paper, we demonstrate long-range transport of Asian trace gases via eddy-shedding events using MIPAS (Michelson Interferometer for Passive Atmospheric Sounding) satellite observations, ERA-Interim reanalysis data and the ECHAM5-HAMMOZ global chemistry-climate model. Model simulations and observations consistently show that Asian boundary layer trace gases are lifted to UTLS altitudes in the monsoon anticyclone and are further transported horizontally eastward and westward by eddies detached from the anticyclone. We present an event of eddy shedding during 1-8 July 2003 and discuss a 1995-2016 climatology of eddy-shedding events. Our analysis indicates that eddies detached from the anticyclone contribute to the transport of Asian trace gases away from the Asian region to the western Pacific $\left(20-30^{\circ} \mathrm{N}, 120\right.$ $\left.150^{\circ} \mathrm{E}\right)$ and western Africa $\left(20-30^{\circ} \mathrm{N}, 0-30^{\circ} \mathrm{E}\right)$. Over the last two decades, the estimated frequency of occurrence of eddy-shedding events is $\sim 68 \%$ towards western Africa and $\sim 25 \%$ towards the western Pacific.

Model sensitivity experiments considering a $10 \%$ reduction in Asian emissions of non-methane volatile organic compounds (NMVOCs) and nitrogen oxides $\left(\mathrm{NO}_{x}\right)$ were performed with ECHAM5-HAMMOZ to understand the impact of Asian emissions on the UTLS. The model simulations show that transport of Asian emissions due to eddy shed-
\end{abstract}

ding significantly affects the chemical composition of the upper troposphere $(\sim 100-400 \mathrm{hPa})$ and lower stratosphere $(\sim 100-80 \mathrm{hPa})$ over western Africa and the western Pacific. The $10 \%$ reduction of NMVOCs and $\mathrm{NO}_{x}$ Asian emissions leads to decreases in peroxyacetyl nitrate (PAN) (2\%$10 \%$ near $200-80 \mathrm{hPa})$, ozone $(1 \%-4.5 \%$ near $\sim 150 \mathrm{hPa})$ and ozone heating rates $\left(0.001-0.004 \mathrm{~K} \mathrm{day}^{-1}\right.$ near 300 $150 \mathrm{hPa}$ ) in the upper troposphere over western Africa and the western Pacific.

\section{Introduction}

Rapid industrialization, traffic growth and urbanization resulted in significant increases in the concentrations of tropospheric trace gases, such as carbon dioxide $\left(\mathrm{CO}_{2}\right)$, carbon monoxide $(\mathrm{CO})$ and methane $\left(\mathrm{CH}_{4}\right)$ over Asia. There is global concern about rising levels of these trace gases (due to their global warming potential) as they are projected to increase further over the coming years despite efforts to implement several mitigation strategies (Ohara et al., 2007). In situ observations, satellite measurements, trajectory analysis and model simulations show long-range transport of Asian trace gases to remote locations (e.g. North America, Europe) (Liang et al., 2004). The transported trace gases change the radiative balance, dynamics and chemical composition at the respective locations (Vogel et al., 2016). Satellite observations show increasing trends in sev- 
eral tropospheric Asian trace gases over the last decade, e.g. ozone at $\sim 1 \% \mathrm{yr}^{-1}-3 \% \mathrm{yr}^{-1}$ (Verstraeten et al., 2015), $\mathrm{CO}$ at $3 \% \mathrm{yr}^{-1}$ (Strode and Pawson, 2013) and $\mathrm{NO}_{x}$ at $\sim 3.8 \% \mathrm{yr}^{-1}-7.3 \% \mathrm{yr}^{-1}$ (Schneider and van der A, 2012; Ghude et al., 2013). Biomass-burning is another major contributor to the observed growth in these trace gases (van der Werf et al., 2006). Peroxyacetyl nitrate (PAN), a powerful pollutant formed in biomass-burning plumes (Wayne, 2000), is a secondary pollutant produced through the oxidation of hydrocarbons released from anthropogenic and biogenic sources. It is a reservoir of reactive nitrogen and plays a fundamental role in the global ozone budget (Tereszchuk et al., 2013; Payne et al., 2017). PAN can also be formed in the upper troposphere through the production of $\mathrm{NO}_{x}$ from lightning (Zhao et al., 2009). Simulations of the Model of Ozone and Related chemical Tracers (MOZART) show an increase of 20\%-30\% of PAN concentrations in the upper troposphere and lower stratosphere (UTLS) over the Asian summer monsoon (ASM) region produced from lightning (Tie et al., 2002). While in the lower troposphere, PAN has a short lifetime (a few hours), in the UTLS it has a longer lifetime (3-5 months) and can therefore act as a reservoir and carrier of $\mathrm{NO}_{x}$ (Tereszchuk et al., 2013). Recent satellite observations show an increasing trend in PAN $(\sim 0.1 \pm 0.05$ to $2.7 \pm 0.8 \mathrm{ppt} \mathrm{yr}^{-1}$ ) in the UTLS over Asia (Fadnavis et al., 2014).

Monsoon convection plays an important role in the lofting of boundary layer Asian air masses to the UTLS (e.g. Randel et al., 2010; Fadnavis et al., 2015; Santee et al., 2017). The uplifted air masses become confined into the anticyclone enclosed by jets (westerly and easterly jets to the north and south, respectively), which act as a strong transport barrier and restrict isentropic mixing into the extratropical lower stratosphere or the equatorial tropics (Ploeger et al., 2015, 2017). Confinements of high concentrations of trace gases, including ozone precursors (e.g. hydrogen cyanide $(\mathrm{HCN})$, $\mathrm{CO}$, hydrochloric acid $(\mathrm{HCl}), \mathrm{NO}_{x}$ and $\left.\mathrm{PAN}\right)$, and low ozone in the anticyclone are evident in satellite and aircraft observations (Randel et al., 2010; Vogel et al., 2014; Fadnavis et al., 2015; Ungermann et al., 2016; Santee et al., 2017). The observed ozone minimum is still an open question in spite of high amounts of its precursors in the anticyclone. A fraction of these trace gases enters the lower stratosphere and affects the UTLS chemical composition (Randel et al., 2010; Fadnavis et al., 2015; Roy et al., 2017; Garny and Randel, 2016), with associated radiative forcing impacts (Riese et al., 2012). Cross-tropopause transport associated with the Asian monsoon is evident in a number of species, including aerosols, hydrogen cyanide (HCN) and PAN (Randel et al., 2010; Fadnavis et al., 2014, 2015; Bourassa et al., 2012).

The ASM anticyclone is highly dynamic in nature (e.g. Hsu and Plumb, 2000; Popovic and Plumb, 2001; Vogel et al., 2016). On the subseasonal scale, it shows variation in strength and location (Garny and Randel, 2016). It frequently sheds eddies, and on occasion, it splits into two anticyclones, namely the Tibetan and Iranian anticyclones (Zhang et al., 2002; Nützel et al., 2016). An eddy detached from the anticyclone carries Asian air masses (trace gases) away from the ASM region. There are scattered studies indicating eddy shedding to the west (Popovic and Plumb, 2001) and east (Ungermann et al., 2016; Vogel et al., 2014) of the anticyclone. An eddy-shedding event causes irreversible mixing in the surrounding air changing the chemical composition and radiative balance of that region (Garny and Randel, 2016). Here, we analyse transport of Asian trace gases via eddies in detail, subsequent mixing into the extratropics and radiative impact of eddy-shedding events on decadal scales. In this study, we answer the following questions: (1) how frequent were eddy-shedding events during the last two decades? (2) Which regions are the most affected? (3) Does the transport of Asian trace gases arising from eddy shedding affect UTLS ozone concentrations and heating rates at remote locations?

To address these questions, we first consider an eddyshedding event demonstrating eastward and westward shedding from the ASM anticyclone during 1-8 July 2003. This year was chosen since the monsoon season was quite normal (i.e. no evidence of El Niño or Indian Ocean dipole phenomenon influencing the monsoon circulation). We then present a climatology of eddy shedding events and lead-lag relations of eddies with the anticyclone. We also evaluate the impact of increasing Asian emissions of $\mathrm{NO}_{x}$ and NMVOCs on ozone and PAN during the eddy-shedding event, using model sensitivity simulations. Finally, we estimate the associated changes in ozone heating rates in the UTLS due to Asian trace gases being transported via eddy-shedding events.

\section{Model set-up and satellite observations}

\subsection{Satellite observations}

The Michelson Interferometer for Passive Atmospheric Sounding (MIPAS) on-board the European ENVIronmental SATellite (ENVISAT) (MIPAS-E) was launched in March 2002 into a polar orbit of $800 \mathrm{~km}$ altitude. Its orbital period is about $100 \mathrm{~min}$. MIPAS-E provided continual limb emission measurements in the mid-infrared over the range $685-2410 \mathrm{~cm}^{-1}(14.6-4.15 \mu \mathrm{m})$ (Fischer et al., 2008). MIPAS monitored many atmospheric trace constituents including $\mathrm{CO}, \mathrm{PAN}$ and $\mathrm{O}_{3}$. The details of the general retrieval method and set-up, error estimates and use of averaging kernel and visibility flag are documented by von Clarmann et al. (2009). Here, we analyse the MIPAS observations of CO, PAN and $\mathrm{O}_{3}$ during 1-8 July 2003.

To account for the comparatively low and altitudedependent vertical resolution of MIPAS, the model data were convolved with the MIPAS averaging kernel to be directly comparable to MIPAS measurements of $\mathrm{CO}, \mathrm{PAN}$ and ozone. 
MIPAS vertical resolution for $\mathrm{CO}, \mathrm{O}_{3}$ and PAN in the UTLS is $5,3.5$ and $5 \mathrm{~km}$, respectively. The data are contoured and gridded. For each grid point, the surrounding MIPAS data points are averaged while applying a distance weighting. The maximum distance for which MIPAS data points are considered is $\pm 7^{\circ}$ in latitude and $\pm 15^{\circ}$ in longitude (covering a box of $14^{\circ}$ in latitude and $30^{\circ}$ in longitude), and a minimum number of two data points per interpolation grid point are required. The data quality specifications as given in the metadata of the MIPAS data files were employed, namely only data with a visibility flag equal to 1 (all gases) and a diagonal value of the averaging kernel greater than 0.03 were used for ozone and PAN, while the diagonal value of the averaging kernel had to exceed 0.008 for $\mathrm{CO}$ to be used (personal communication with with Bernd Funke, 2018; see also Glatthor et al., 2007; Funke et al., 2009).

\subsection{Model set-up}

We employ the ECHAM5-HAMMOZ (Roeckner et al., 2003) aerosol-chemistry-climate model to understand redistribution of Asian trace gases via eddy shedding from the anticyclone. ECHAM5-HAMMOZ comprises the general circulation model ECHAM5 (Roeckner et al., 2003), the tropospheric chemistry module MOZ (Horowitz et al., 2003) and the aerosol module Hamburg Aerosol Model (HAM) (Stier et al., 2005). The chemistry of ozone, VOCs, $\mathrm{NO}_{x}$, and other gas-phase species is based on the MOZART-2 chemical scheme (Horowitz et al., 2003). It includes $\mathrm{O}_{x}-\mathrm{NO}_{x}$ hydrocarbons with 63 tracers and 168 reactions. The details of the parameterizations and emissions used in the model as well as a validation of the results are described by Fadnavis et al. (2013, 2014, 2015) and Pozzoli et al. (2011).

The model simulations were performed with a T42 spectral resolution corresponding to about $2.8^{\circ} \times 2.8^{\circ}$ in the horizontal dimension and 31 vertical hybrid $\sigma-p$ levels from the surface up to $10 \mathrm{hPa}$. Here, we note that our base year for aerosol and trace gas emissions is 2000 . We performed two simulations: (i) a control experiment (CTRL) and (ii) a sensitivity experiment (Asia-10), where emissions of both $\mathrm{NO}_{x}$ and NMVOCs were simultaneously reduced by $10 \%$ over Asia $\left(10^{\circ} \mathrm{S}-50^{\circ} \mathrm{N}, 60-130^{\circ} \mathrm{E}\right)$ similarly to earlier publications (Naik et al., 2005; Fadnavis et al., 2015). This fixed $10 \%$ reduction was chosen due to the spatial-temporal variability of NMVOCs over Asia and the inherent difficulty in obtaining a common trend value (Li et al., 2014). The impacts of this NMVOCs and $\mathrm{NO}_{x}$ emission perturbation are investigated by analysing the associated anomalies (Asia-10 - CTRL) in ozone, PAN and ozone heating rates.

Both simulations were performed for the year 2003 driven by European Centre for Medium-Range Weather Forecasts operational analyses (Integrated Forecast System, IFS, cycle$32 \mathrm{r} 2$ ) meteorological fields (available every $6 \mathrm{~h}$ ) (Uppala et al., 2005). All simulations include lightning $\mathrm{NO}_{x}$ and the subsequent PAN production. Since the lightning parameteri- zation is the same in the CTRL and sensitivity simulations, its impact may be negligible. However, there may be an indirect impact of changed emissions on lightning and thus on $\mathrm{NO}_{x}$ or PAN production. The model simulations used here are the same as those used by Fadnavis et al. (2015). The climatology of ozone mass mixing ratio, winds and potential vorticity $(\mathrm{PV})$ are obtained from ERA-Interim reanalysis data for the period 1995-2016. The anomalies are obtained from differences between daily mean values of July 2003 and daily climatology. Power spectral analysis and lag-lead correlations have been carried out on PV data for the period 1995-2016 to show climatological features.

Instantaneous ozone heating rates are calculated using the Edwards and Slingo (1996) radiative transfer model. We used the offline version of the model, with six shortwave and nine long-wave bands, and a delta-Eddington 2-stream scattering solver at all wavelengths in a set-up similar to other recent studies (Rap et al., 2015, Roy et al., 2017).

\section{Results}

\subsection{A typical case study of eddy shedding from the monsoon anticyclone}

The dynamics of the monsoon anticyclone is best portrayed at the $370 \mathrm{~K}$ potential temperature surface and the monsoon anticyclone is obvious as an area of low PV values $\left(\mathrm{PV}<2 \mathrm{PVU}, 1 \mathrm{PVU}=10^{-6} \mathrm{~K} \mathrm{~m}^{2} \mathrm{~kg}^{-1} \mathrm{~s}^{-1}\right.$ ) (indicating tropospheric air mass) at this surface (Garny and Randel, 2016). Eddies are identified as air with low PV emanating from the monsoon anticyclone (Popovic and Plumb, 2001; Vogel et al., 2014). Past studies have shown that, during the monsoon season (June to September), the bulk of the low PV air at the isentropic level of $370 \mathrm{~K}$ is confined between about $20-35^{\circ} \mathrm{N}$ and $20-120^{\circ} \mathrm{E}$, indicating the spatial extent of the anticyclone (Popovic and Plumb, 2001; Vogel et al., 2014; Garny and Randel, 2016). A pocket of low PV air mass detached from the boundary of the anticyclone (outside the anticyclone, $20-35^{\circ} \mathrm{N}$ and $20-120^{\circ} \mathrm{E}$ ) is considered as an eddy. Figure $1 \mathrm{a}-\mathrm{h}$ show the distribution of PV at $370 \mathrm{~K}$ during 1-8 July 2003. It can be seen that during this period the anticyclone was wobbling and shedding eddies eastward and westward over western Africa $\left(20-30^{\circ} \mathrm{N}, 0-30^{\circ} \mathrm{E}\right)$ and the western Pacific $\left(20-30^{\circ} \mathrm{N} ; 120-150^{\circ} \mathrm{E}\right)$. Initially, during $2-$ 5 July 2003, the ASM anticyclone shed an eddy westward over western Africa. The eddy moved further west with the progression of time. Later during 4-8 July 2003, eddy shedding occurred to the east of the anticyclone, over the western Pacific and the air detached from the anticyclone moved further eastward with time. The longitude-pressure section of $\mathrm{PV}$ shows that the eddy protrudes down to $400 \mathrm{hPa}$ (not shown).

Previous studies have shown that eddy-shedding events are associated with Rossby wave breaking (RWB) (Hsu and 


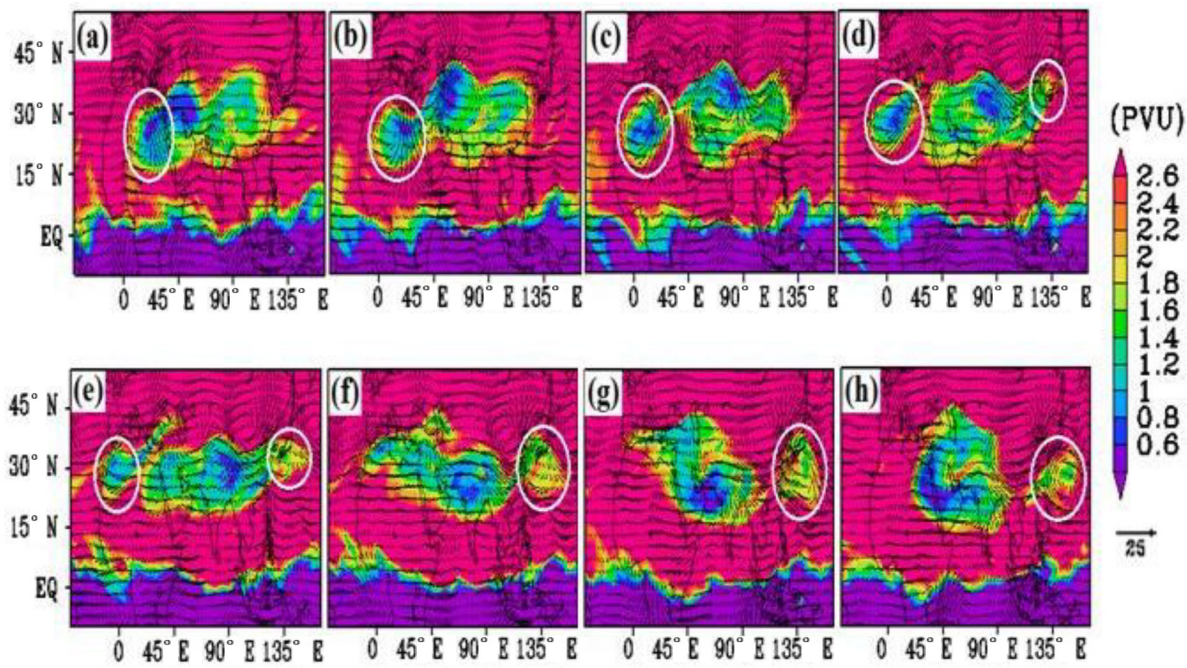

Figure 1. Spatial distribution of potential vorticity (PVU) (1 PVU $=10^{-6} \mathrm{~K} \mathrm{~m}^{2} \mathrm{~kg}^{-1} \mathrm{~s}^{-1}$ ) (colour shades) at $370 \mathrm{~K}$ potential temperature surface and wind anomalies at $200 \mathrm{hPa}$ from ERA-Interim reanalysis for (a) 1 July, (b) 2 July, (c) 3 July, (d) 4 July, (e) 5 July, (f) 6 July, (g) 7 July and (h) 8 July 2003. Wind vectors are represented by black arrows ( $\mathrm{m} \mathrm{s}^{-1}$ ). Eddies are shown with white circles.

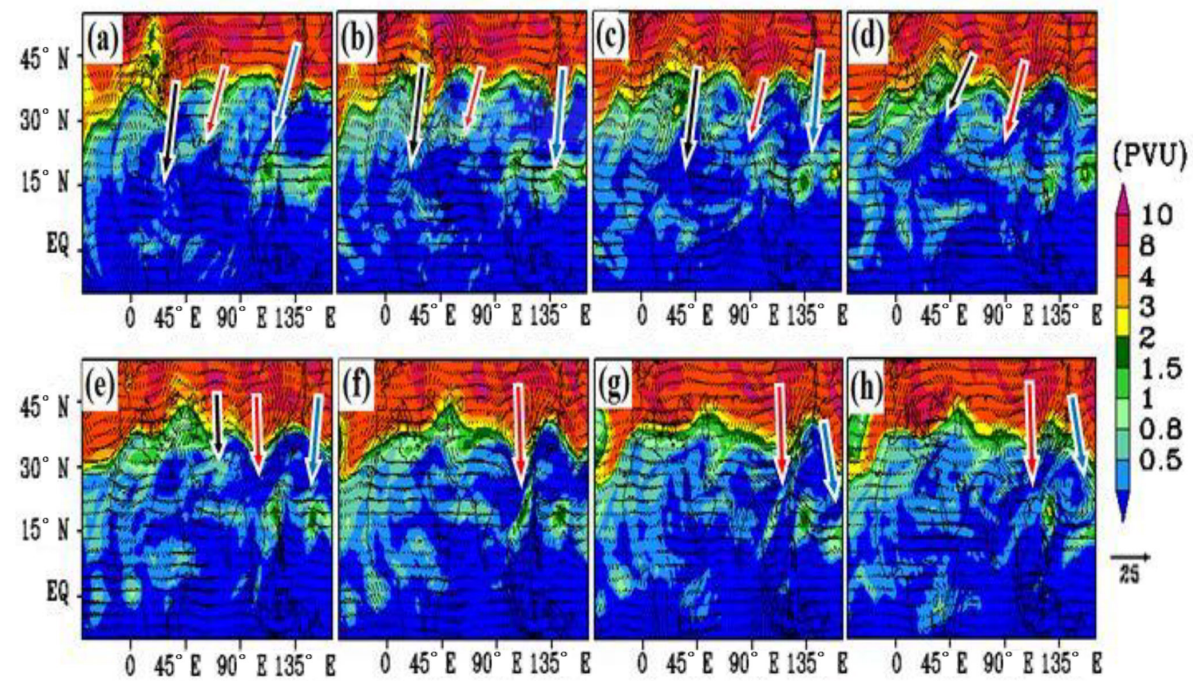

Figure 2. Spatial distribution of potential vorticity (PVU) (colour shades) at $350 \mathrm{~K}$ potential temperature surface and wind anomalies in $\mathrm{m} \mathrm{s}^{-1}$ (thin black vectors) at $200 \mathrm{hPa}$ from ERA-Interim reanalysis for (a) 1 July, (b) $2 \mathrm{July}$, (c) 3 July, (d) 4 July, (e) 5 July, (f) 6 July, (g) 7 July and (h) 8 July 2003. The events of RWB-1, RBW-2 and RWB-3 are indicated by solid black, red and blue arrows, respectively.

Plumb, 2000; Popovic and Plumb, 2001; Fadnavis and Chattopadhyay, 2017). The RWB is manifested as a rapid and large-scale irreversible overturning of PV contours on the $350 \mathrm{~K}$ isentropic surface. It is accompanied with a cyclonic circulation at $200 \mathrm{hPa}$ (Strong and Magnusdottir, 2008; Fadnavis and Chattopadhyay, 2017). Figure $2 \mathrm{a}-\mathrm{h}$ show the distribution of PV at the $350 \mathrm{~K}$ surface and the circulation at $200 \mathrm{hPa}$ during $1-8$ July 2003 . It can be seen that, during 1-8 July 2003, three RWB events occurred: one near $30^{\circ} \mathrm{E}$ (referred as RWB-1), one near $70^{\circ} \mathrm{E}$ (referred as RWB-2) and another one near $120^{\circ} \mathrm{E}$ (referred to as RWB-3). Since
RWB-3 was outside the region of the ASM anticyclone (over the western Pacific $\sim 150-170^{\circ}$ E), it did not play a role in the eddy-shedding event of 1-8 July. If we track the locations of these RWB events (indicated by the black and red arrows), one can see that, with the progression of time, the RWB feature moved eastward. The eastward migration of RWB is linked to its movement along the subtropical westerly jet (Fadnavis and Chattopadhyay, 2017). Initially, during 1-5 July, RWB-1 was strong (PV > 2 PVU), while RWB-2 $(\mathrm{PV}<2 \mathrm{PVU})$ was weak. During this period the southwardand westward-moving RWB-1 leads to eddy shedding over 
western Africa. Later, during 4-8 July, RWB-2 strengthened while RWB-1 weakened and disappeared. The southwardand eastward-moving RWB-2 was responsible for the eddyshedding event near the western Pacific (see Fig. 2d-h).

\subsection{Climatology of eddy shedding from the monsoon anticyclone}

A power spectrum analysis (PSA) has been performed on the PV data (averaged for 300-100 hPa) during 1995-2016 for western Africa $\left(20-30^{\circ} \mathrm{N}, 0-30^{\circ} \mathrm{E}\right)$ and the western Pacific $\left(20-30^{\circ} \mathrm{N}, 140-150^{\circ} \mathrm{E}\right)$. The PSA uses the temporalto-frequency fast Fourier transform in order to identify dominant signal frequencies. It provides information on signal power (square of variance) associated with the frequency components of the signal, with the dominant signal periodicity being the inverse of the dominant signal frequency. Figure $3 \mathrm{a}-\mathrm{b}$ show the distribution of power spectral variance over the western Africa and western Pacific regions. The variances corresponding to the periodicities of 3-5 days, 12-15 and 18-21 days are significant at $95 \%$ confidence level for both the regions, indicating that the eddy-shedding activity is dominated in the range of synoptic frequency ( $\sim 10$ days). Popovic and Plumb (2001) also indicated a typical duration of an eddy-shedding event of $\sim 4-8$ days. We compute the frequency of eddy-shedding days (PV $<1 \mathrm{PVU})$ occurring over western Africa and the western Pacific. The ERA-Interim data for the last two decades show that eddy shedding is quite frequent over western Africa $(\sim 68 \%)$ and the western Pacific $(\sim 25 \%)$. The lag-lead correlation of PV (averaged for 200-100 hPa) for the central region of the anticyclone $\left(85-90^{\circ} \mathrm{E}, 28-30^{\circ} \mathrm{N}\right)$ with $\mathrm{PV}$ averaged over the western Pacific shows a maximum positive lead correlation at 3-4 days (Fig. 3c). Similarly, PV over western Africa shows a maximum positive lead correlation for 5-6 days with the PV averaged over the monsoon anticyclone (Fig. 3d). This indicates that the transport of the eddies from the anticyclone (source region) has a typical duration of 3 to 4 days over the western Pacific and 5 to 6 days over western Africa. This transport time is the timescale over which the trace gases are moved to remote locations from the ASM anticyclone.

\subsection{Long-range transport of trace gases}

\subsubsection{Horizontal transport of ozone, $\mathrm{CO}$ and PAN via eddies}

Biomass burning over south-east Asia and east Asia produces large amounts of $\mathrm{CO}, \mathrm{NO}_{x}$, VOCs, PAN, ozone and aerosols (e.g. Streets et al., 2003; Fadnavis et al., 2014). The monsoon convection over the Bay of Bengal, southern slopes of Himalaya and South China Sea (see Fig. S1 in the Supplement) lifts up these species into the anticyclone, where they may be dispersed in the UTLS by the vibrant anticyclone and its associated eddies. Figure $4 \mathrm{a}-\mathrm{h}$ show the distri- bution of ozone during 1-8 July 2003 (MIPAS $\mathrm{O}_{3}$ is binned for 2 days and simulated $\mathrm{O}_{3}$ is plotted for alternate days) in the anticyclone at $16 \mathrm{~km}(\sim 100 \mathrm{hPa})$. Ozone concentrations from MIPAS satellite measurements and model simulations (CTRL) are plotted at $16 \mathrm{~km}$ and from ERA-Interim reanalysis at $100 \mathrm{hPa}$. For comparison, we interpolated the model data to the MIPAS altitude grid and smoothed it with the averaging kernel. The ASM anticyclone is marked by minimum ozone although its precursors (e.g. $\mathrm{CO}, \mathrm{NO}_{x}$ and $\mathrm{CH}_{4}$ ) show maxima (Randel et al., 2010; Roy et al., 2017). The spatial pattern of low amounts of ozone in the anticyclone and the associated eddies is evident in all of the data sets during 1-8 July 2003. The locations of ozone local minima in the model are slightly shifted relative to the locations of eddies and relative to the locations of ozone local minima in MIPAS and ERA. During 1-5 July, ozone concentrations in the eddy over western Africa are $\sim 40-200 \mathrm{ppb}$ in MIPAS, $\sim 60-180 \mathrm{ppb}$ in ERA-Interim and 100-200 ppb in the model simulations. During 4-8 July, the eddy over the western Pacific shows ozone values of $\sim 60-180$ ppb in MIPAS, $\sim 60-180 \mathrm{ppb}$ in ERA-Interim and $\sim 120-200 \mathrm{ppb}$ in the model simulations. In general, the model overestimates ozone by $\sim 60 \mathrm{ppb}$ more than ERA-Interim and MIPAS measurements.

Figure 5a-h show the distribution of CO from MIPAS observations and model simulations during 1-8 July 2003 (MIPAS CO is binned for 2 days and simulated $\mathrm{CO}$ is plotted for alternate days). The confinement of high concentrations of $\mathrm{CO}$ in the anticyclone and in eddies is seen in both MIPAS observations and model simulations. During 1-5 July, eddies over western Africa and western Pacific show CO volume mixing ratios of $\sim 85-95 \mathrm{ppb}$ in MIPAS and $\sim 70-95 \mathrm{ppb}$ in the model simulations. Similarly to ozone the maximum in the $\mathrm{CO}$ distribution is not collocated with eddies. Further, slight differences between model simulations and MIPAS observations are found. These differences may be due to coarse resolution, uncertainties in emissions, chemistry represented and transport processes in the model.

Figure $6 \mathrm{a}-\mathrm{h}$ show the distribution of PAN from MIPAS measurements and the model simulation (CTRL) at $16 \mathrm{~km}$ during 1-8 July 2003 (MIPAS PAN mixing ratios are binned for 2 days and simulated PAN is plotted for alternate days). A confinement of high amounts of PAN in the anticyclone and the associated eddies is seen both in the MIPAS measurements and the model simulations. During 1-5 July, MIPAS observed amounts of PAN are $~ 120-240$ ppt in eddies over western Africa, while the model simulation shows $\sim 180$ $240 \mathrm{ppt}$ of PAN at the same location. The eddy over the western Pacific shows PAN values of 160-240 ppt both in MIPAS measurements and model simulations.

There are differences in amounts of ozone, $\mathrm{CO}$ and PAN from model simulation, satellite observations and ozone from ERA-Interim. These differences may be due to a number of reasons, e.g. different grid sizes on MIPAS, ERA-Interim and model data, binning of MIPAS data for 2 days to accom- 
(a)

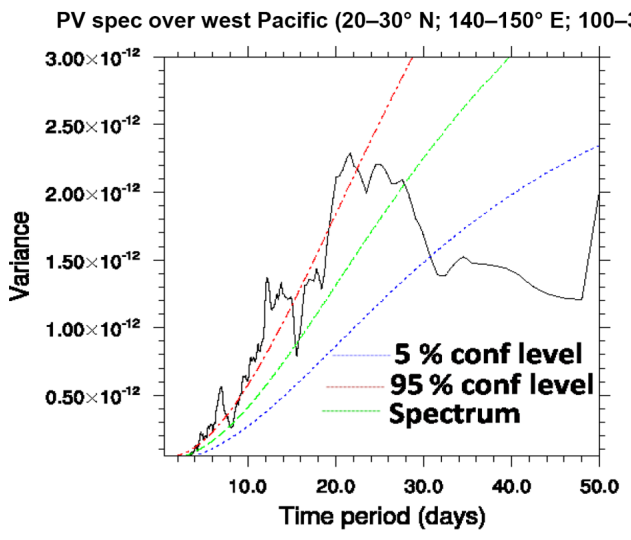

(c)

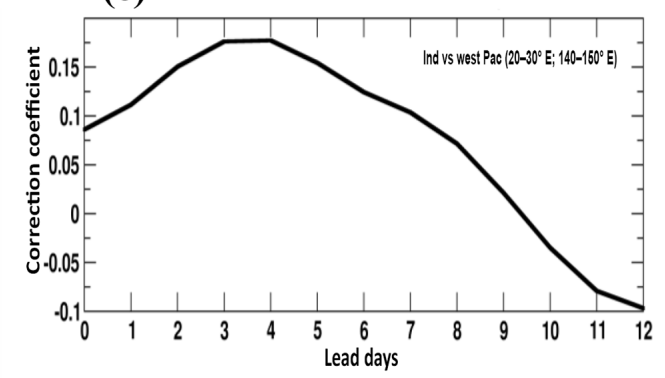

(b)

PV spec over west Africa $\left(20-30^{\circ} \mathrm{N} ; 0-30^{\circ} \mathrm{E} ; 100-300 \mathrm{hPa}\right)$

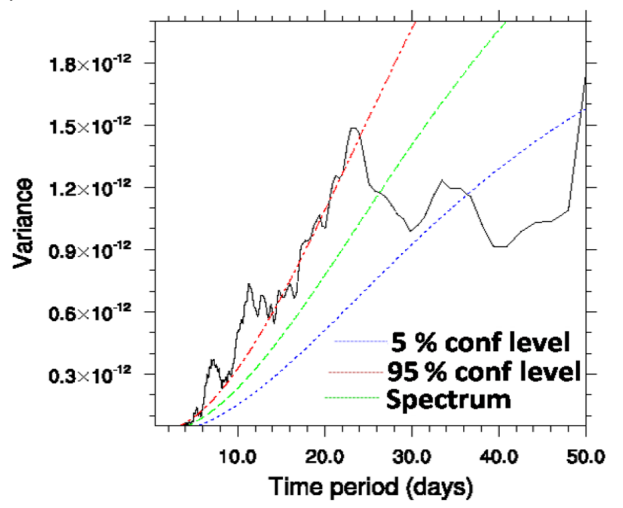

(d)

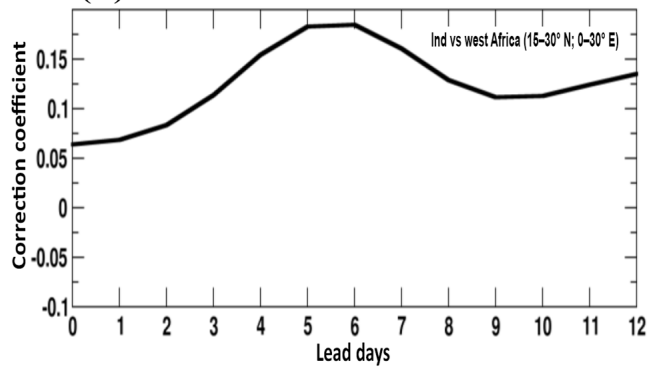

Figure 3. Power spectral analysis of ERA-Interim PV averaged for 100-300 hPa and in June-September during 1995-2015 for (a) western Africa $\left(20-30^{\circ} \mathrm{N}, 0-30^{\circ} \mathrm{E}\right)$ and (b) western Pacific $\left(20-30^{\circ} \mathrm{N}, 140-150^{\circ} \mathrm{E}\right)$ and lag-lead Pearson correlation coefficient of PV in the monsoon anticyclone $\left(85-90^{\circ} \mathrm{E}, 28-30^{\circ} \mathrm{N}\right)$ with (c) western Pacific $\left(20-30^{\circ} \mathrm{N}, 140-150^{\circ} \mathrm{E}\right)$ and (d) western Africa $\left(20-30^{\circ} \mathrm{N}, 0-30^{\circ} \mathrm{E}\right)$. In (a)-(b) the dotted green line indicates the spectrum and blue and red lines indicate $5 \%$ and $95 \%$ confidence levels for lag- 1 autocorrelation. Any spectral peak above the red line is statistically significant at the $95 \%$ confidence level.

modate better spatial coverage, uncertainties in the model emission inventory and retrieval errors in the satellite data. A maximum in PAN near the location of eddies differs in MIPAS and model. Comparison of Fig. 1 and Figs. 4-6 shows that the minimum in ozone and maximum in $\mathrm{CO}$ and PAN is not collocated at eddies. The location varies slightly in species and data sets (in MIPAS, ERA and model). This may be due to differences in data sets and production and loss processes of each species.

\subsubsection{Vertical distribution of CO, PAN and ozone}

Further, we analyse the vertical distribution of $\mathrm{CO}$ and PAN as an indication of Asian biomass-burning emissions. Figure 7 shows longitude-pressure cross sections (averaged for $20-40^{\circ} \mathrm{N}$ ) of $\mathrm{CO}$ and PAN from the CTRL simulation, with wind vectors depicting circulation patterns. It illustrates that during 1-5 July 2003 a plume of CO and PAN was uplifted from the Asian region $\left(80-120^{\circ} \mathrm{E}\right)$, moving further upward into the UTLS. The location of the plume (Fig. 7) coincides with a strong convection region - see Fig. S1 - showing combined cloud droplet (CDNC) and ice crystal (ICNC) number concentrations from the CTRL simulation. Figures 7 and S1 together indicate that surface emissions are lifted up by the monsoon convection. In the upper troposphere $(\sim 120 \mathrm{hPa})$, westward horizontal transport of CO/PAN towards western Africa is obvious as a result of eddy shedding during the respective days. In particular, during 2-4 July high amounts of $\mathrm{CO}$ and PAN are observed near $0-30^{\circ} \mathrm{E}$ at $100 \mathrm{hPa}$ (Fig. 7a$\mathrm{b}$ and $\mathrm{e}-\mathrm{f})$. On 2 July, there is some PAN transport over the western Pacific. During 4-8 July 2003, eddy shedding occurs to the east of the anticyclone over the western Pacific $\left(120-150^{\circ}\right.$ E) (see Fig. 1e-f). Eastward horizontal transport of CO/PAN in the regions of eddy shedding is evident in Fig. 7c-d and g-h. The Asian trace gases then disperse downward into the troposphere (to $\sim 500 \mathrm{hPa}$ over the western Pacific and to $\sim 200 \mathrm{hPa}$ over western Africa) and are partially lifted into the lower stratosphere.

The vertical distribution of ozone shows low amounts of ozone extending from the convective regions of the Bay of Bengal and the South China Sea $\left(\sim 15-25^{\circ} \mathrm{N}\right)$ to the upper troposphere (Fig. S2a-d), with amounts of ozone of $\sim 100$ 200 ppb near the tropopause (see also Fig. 4i-1). The lower amounts of ozone over the Asian troposphere may be due to 

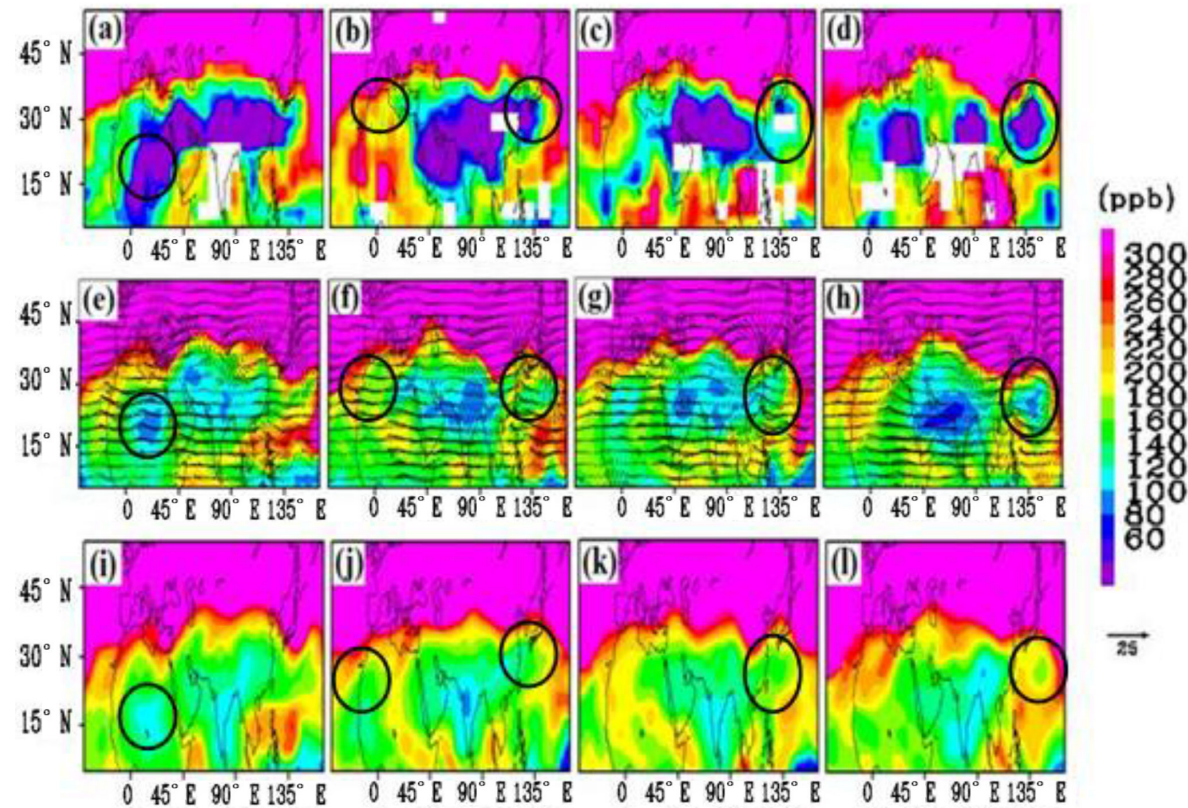

Figure 4. Spatial distribution of ozone mixing ratios (ppb) (colour shades) corresponding to MIPAS satellite observations at $16 \mathrm{~km}$ for (a) $1-$ 2 July, (b) 3-4 July, (c) 5-6 July, (d) 7-8 July 2003; ERA-Interim reanalysis at $100 \mathrm{hPa}$ for (e) 2 July, (f) 4 July, (g) 6 July and (h) 8 July 2003 , and ECHAM5-HAMMOZ CTRL simulations at $16 \mathrm{~km}$ for (i) 2 July, (j) 4 July, (k) 6 July and (l) 8 July 2003. Black arrows in panels (e)-(h) show wind anomalies $\left(\mathrm{m} \mathrm{s}^{-1}\right)$ at $200 \mathrm{hPa}$. Minimum amounts of ozone near the location of eddies are shown with black circles.

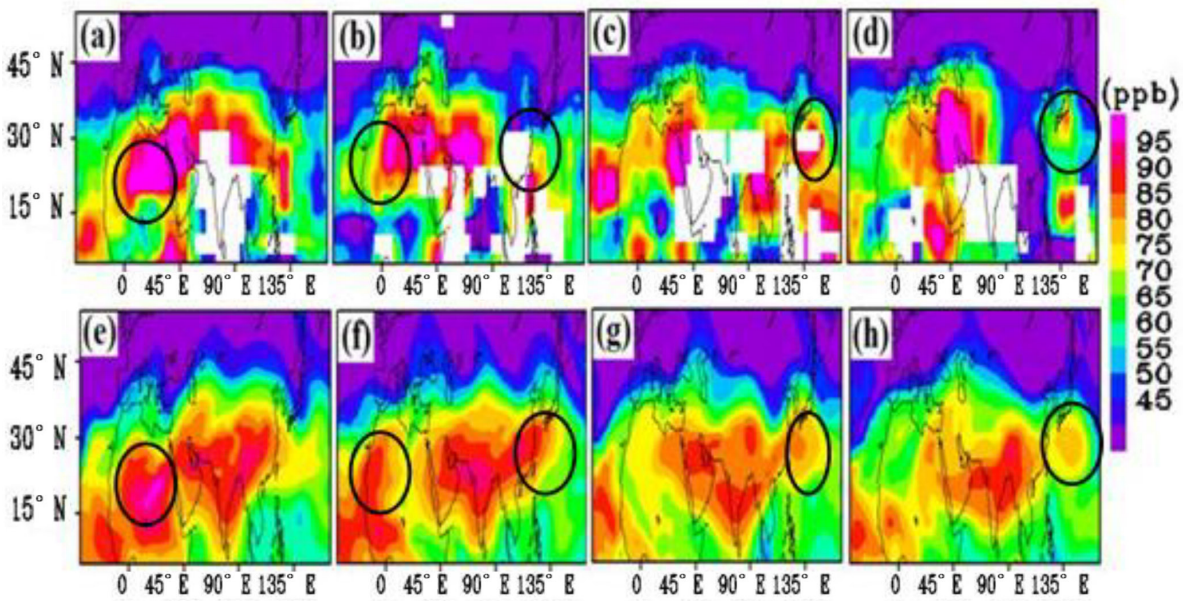

Figure 5. Spatial distribution of CO mixing ratios (ppb) at $16 \mathrm{~km}$ : MIPAS satellite observations for (a) 1-2 July, (b) 3-4 July, (c) 5-6 July, (d) 7-8 July 2003 and ECHAM5-HAMMOZ CTRL simulations for (e) 2 July, (f) 4 July, (g) 6 July and (h) 8 July 2003. Maximum amounts of $\mathrm{CO}$ near the location of eddies are shown with black circles.

clean marine air masses during the monsoon season (Zhao et al., 2009). The feature of low ozone air mass ascent is less evident than the $\mathrm{CO}$ and PAN vertical ascent due to a number of factors which influence ozone production and loss processes at different altitudes in the troposphere and lower stratosphere, such as stratospheric intrusions, lightning, etc. (see discussions in Sect. 3.4).

\subsection{Influence of Asian emissions on extratropical UTLS}

In this section, we investigate the influence of Asian anthropogenic emissions of NMVOCs and $\mathrm{NO}_{x}$ on the distribution of PAN and ozone in the tropical/extratropical UTLS from sensitivity experiments. Figure $8 \mathrm{a}-\mathrm{d}$ show anomalies of PAN (Asia-10-CTRL) at 16km during 1-8 July 2003 (plotted on alternate days). The negative anomalies in PAN are seen confined to the region of the anticyclone and the associ- 

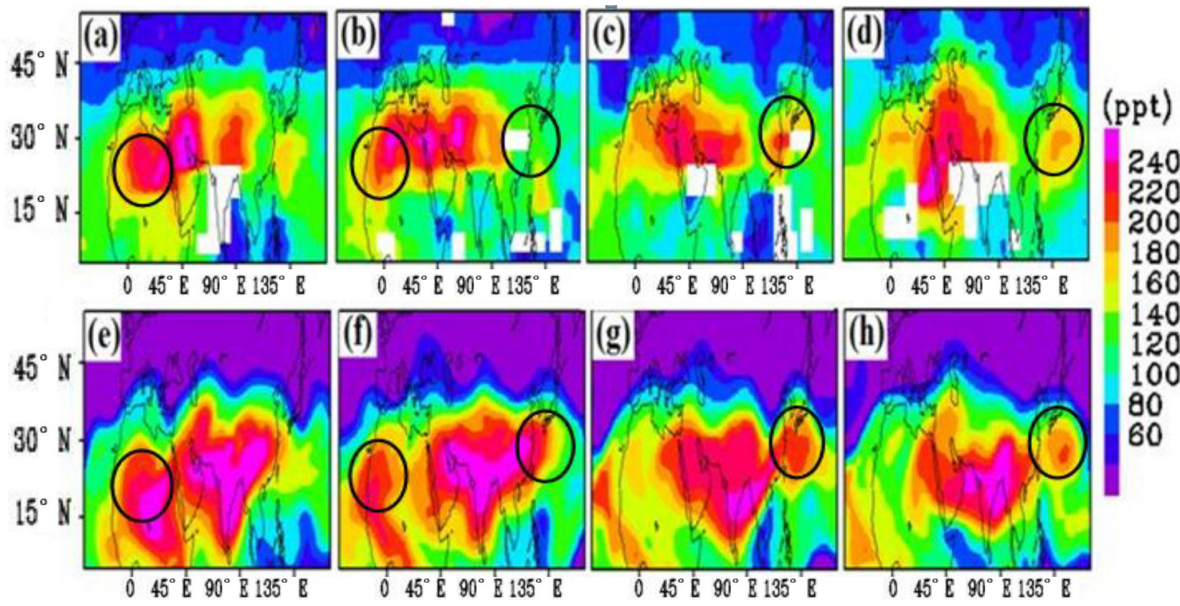

Figure 6. Spatial distribution of PAN mixing ratios (ppt) at $16 \mathrm{~km}$ : MIPAS satellite observations for (a) 1-2 July, (b) 3-4 July, (c) 5-6 July and (d) 7-8 July 2003, and ECHAM5-HAMMOZ CTRL simulations for (e) 2 July, (f) 4 July, (g) 6 July and (h) 8 July 2003 . Maximum amounts of PAN near the location of eddies are shown with black circles.
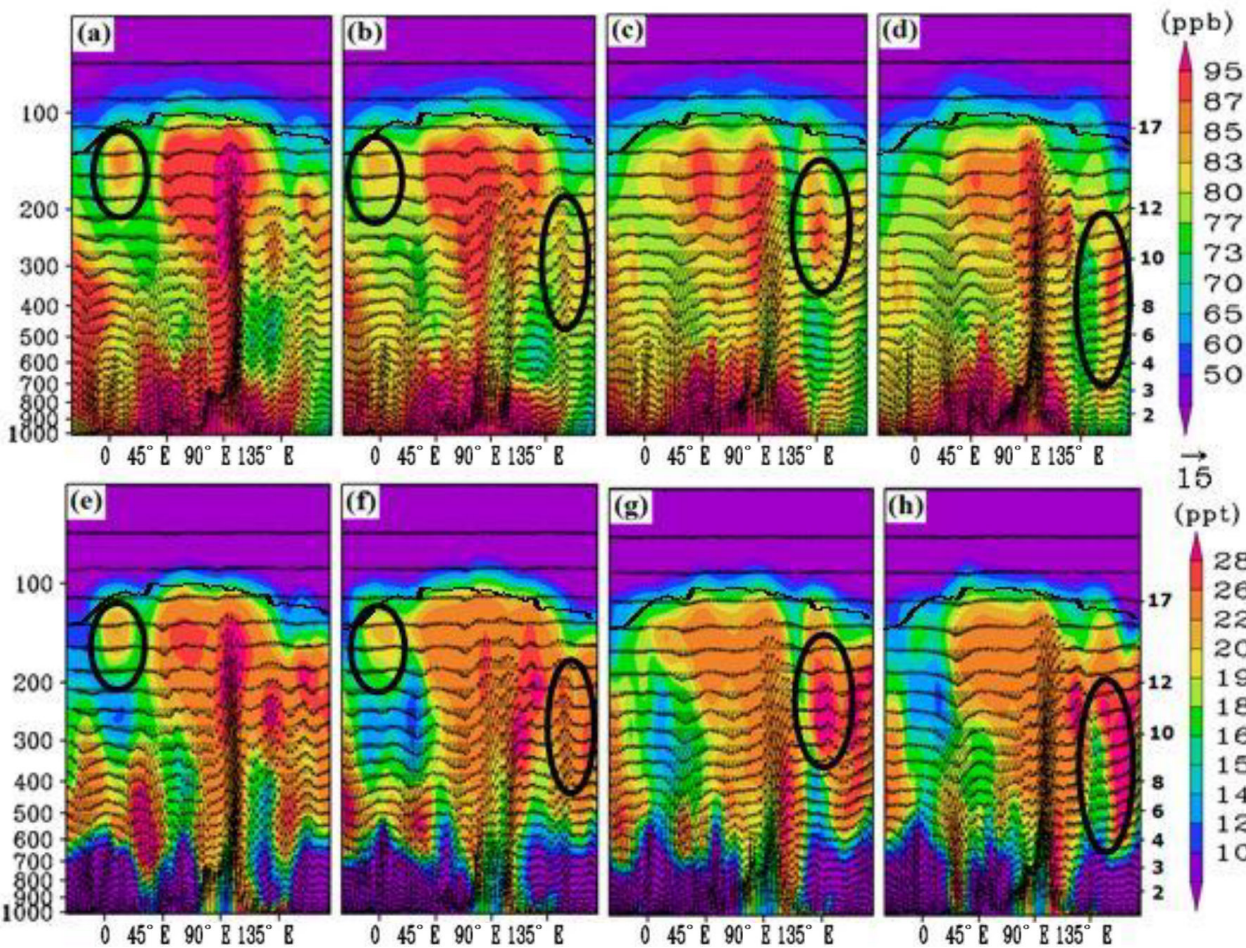

$\overrightarrow{15}$

(ppt)

280

260

220

200

180

150

140

120

100

Figure 7. Longitude-pressure section (averaged for $20-40^{\circ} \mathrm{N}$ ) of CO (ppb) from ECHAM5-HAMMOZ CTRL simulation for (a) 2 July, (b) 4 July, (c) 6 July and (d) 8 July 2003. (e)-(h) same as (a)-(d) but for PAN (ppt). Thick black line indicates the tropopause and black dotted circles indicate maximum amounts of $\mathrm{CO}$ and PAN near eddies. Pressure (hPa) is indicated on the left $y$ axis and altitudes (km) on the right $y$ axis. Wind vectors $\left(\mathrm{m} \mathrm{s}^{-1}\right)$ are shown by black arrows. Vertical velocity field is scaled by a factor of 300 .

ated eddies (1-5 July over western Africa and 4-8 July over the western Pacific). These anomalies portray the effect of Asian boundary layer emissions (NMVOCs and $\mathrm{NO}_{x}$ ) on the upper level anticyclone and the associated eddies. A number of studies (Randel et al., 2010; Fadnavis et al., 2013, 2015; Vogel et al., 2014) have shown lifting of Asian emissions to the UTLS by the monsoon convection and its confinement in the anticyclone. A $10 \%$ decrease in Asian NMVOCs and $\mathrm{NO}_{x}$ emissions decreases amounts of PAN by $\sim 5-23 \%$ in the ASM anticyclone and the associated eddies over western Africa and the western Pacific. 

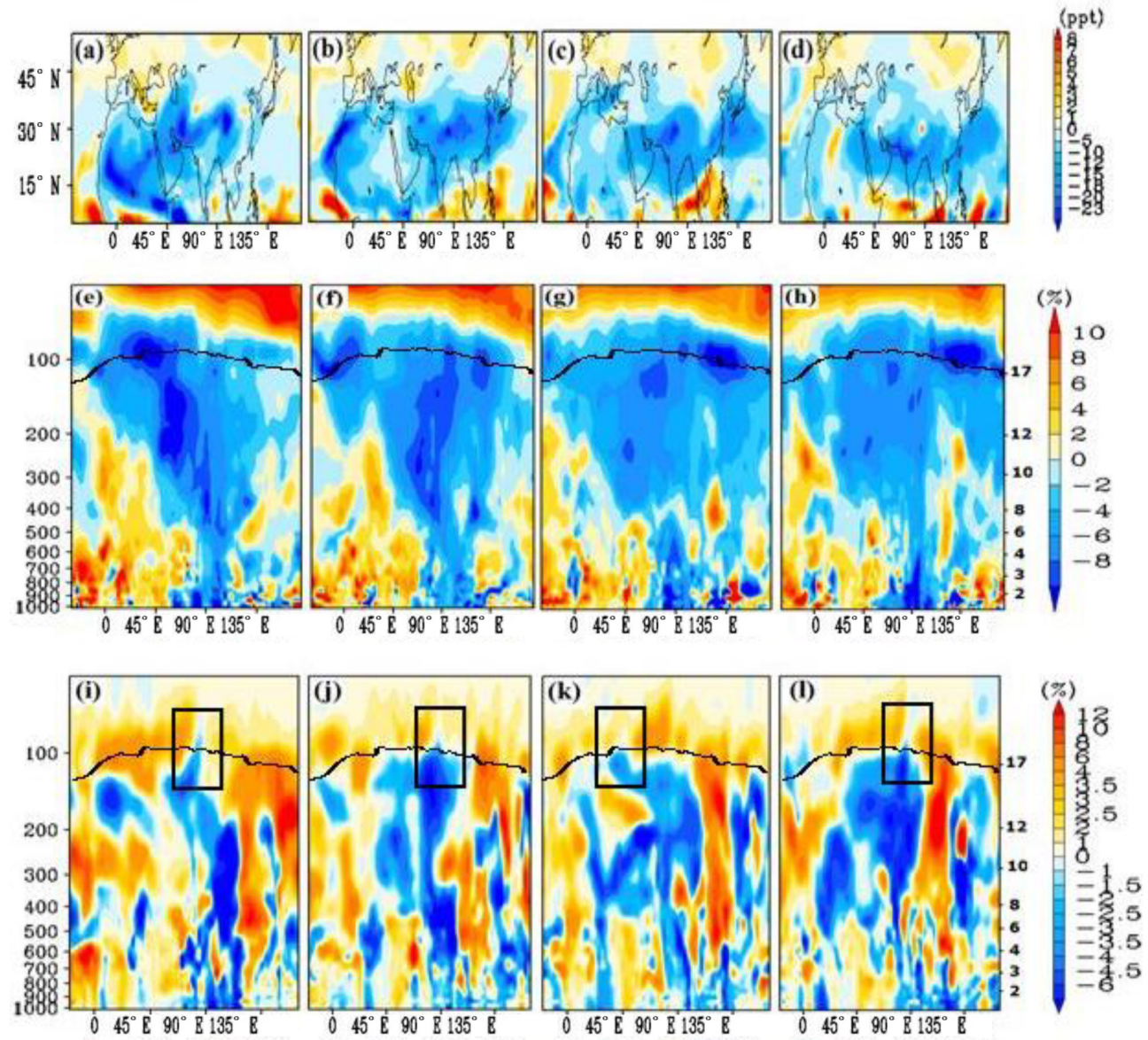

Figure 8. Spatial distribution of anomalies (Asia-10-CTRL) of PAN mixing ratios (ppt) (colour shades) at 16 km from ECHAM5-HAMMOZ model simulations for (a) 2 July, (b) 4 July, (c) 6 July, (d) 8 July 2003. Longitude-pressure distribution (averaged for 20-40 $\mathrm{N}$ ) of anomalies of PAN (\%) for (e) 2 July, (f) 4 July, (g) 6 July and (h) 8 July 2003. Panels (i)-(l) are the same as (e)-(h) but for ozone anomalies (\%) (averaged for $18-20^{\circ} \mathrm{N}$ ). Thick black line indicates the tropopause. Pressure $(\mathrm{hPa})$ is indicated on the left $y$ axis and altitudes $(\mathrm{km})$ on the right $y$ axis. Black boxes in the bottom panels indicate regions of cross-tropopause transport.

Further, we analyse the vertical distribution of anomalies of PAN and ozone. Figure 8e-h show longitude-pressure sections of anomalies of PAN. It shows negative anomalies (in response to reduced Asian emissions) along the transport pathways (Fig. S1), i.e. from the boundary layer of the Asian region $\left(80-120^{\circ} \mathrm{E}\right)$ into the upper troposphere and westward/eastward transport from the anticyclone owing to eddy shedding. These anomalies extend above the tropopause, indicating cross-tropopause transport. Upward transport across the tropopause in monsoon season has been demonstrated to occur in recent tracer studies (Ploeger et al., 2017; Vogel et al., 2018). PAN is rather long-lived in the cold tropopause region and should therefore behave similarly to inert trace gases in the model simulation (Fadnavis et al., 2014, 2015). Our simulations show that a $10 \%$ reduction in Asian emissions of both NMVOCs and $\mathrm{NO}_{x}$, results in a decrease in the amount of PAN by $\sim 2-10 \%$ over north-western Africa during 1-5 July and over the western Pacific during 48 July 2003.

The vertical distribution of ozone anomalies (Fig. 8i-l) show negative values $(-1$ to $-4.5 \%)$ in the troposphere extending from the surface up to $\sim 180 \mathrm{hPa}$ along the transport pathways $\left(\sim 90^{\circ} \mathrm{E}\right)$ and in the region from where crosstropopause transport occurs. Near the tropopause (except in the region of cross-tropopause transport; indicted by boxes in Fig. 8i-l) ozone anomalies are positive, varying between 1 and $8 \%$ (Fig. 8i-1). In contrast to PAN, ozone will be chemically active during the slow ascent over the monsoon area for several months (Vogel et al., 2018). Ozone loss rates are likely to be affected in the Asia-10 simulations. For example reduced $\mathrm{NO}_{x}$ will lead to a lower efficiency of ozone loss providing a reason for higher ozone in the Asia-10 runs. Further, less NMVOCs in Asia-10 simulations might lead to lower $\mathrm{OH}$ concentrations in the lowermost stratosphere above the monsoon region. The major ozone loss 

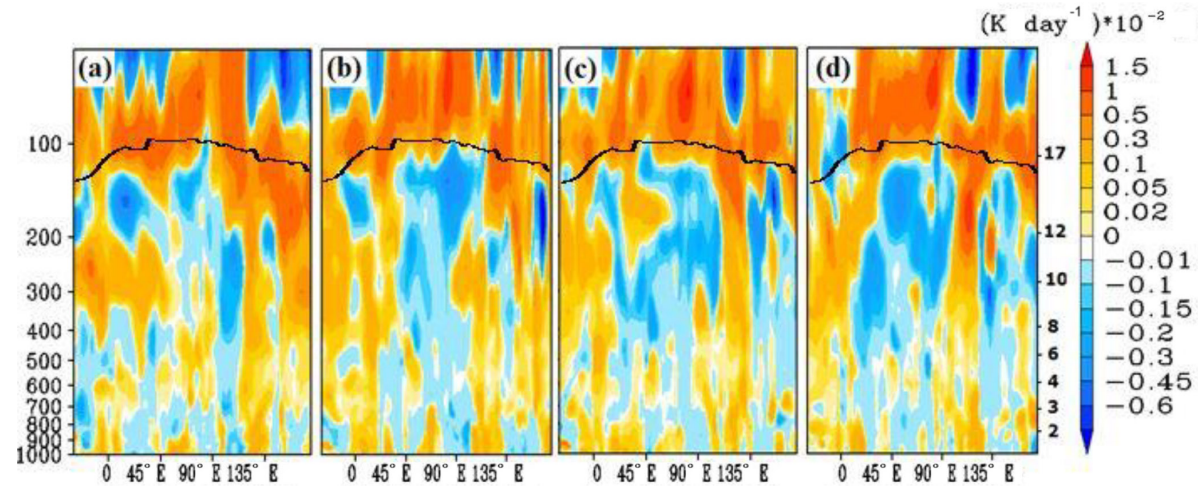

Figure 9. Longitude-pressure distribution (averaged for $\left.18-20^{\circ} \mathrm{N}\right)$ of anomalies of ozone heating rates $\left(\left(\mathrm{K} \mathrm{day}^{-1}\right) \times 10^{-2}\right)$ for $($ a) 2 July, (b) 4 July, (c) 6 July and (d) 8 July 2003. Pressure (hPa) is indicated on the left $y$ axis and altitudes (km) on the right $y$ axis. The thick black line indicates the tropopause.

cycle in the lowermost stratosphere in the tropics is driven by $\mathrm{HO}_{x}$ radicals with the rate limiting step being the reaction of $\mathrm{OH}$ with ozone. The anomalies of $\mathrm{OH}$ concentrations are negative near the tropopause indicating lower ozone loss rates (Fig. S3). The changes in dynamics (e.g stratospheric intrusions and lightning) due to emission sensitivity may also partially contribute to positive anomalies of ozone near the tropopause. Ozone distributions from CTRL simulations show stratospheric intrusion in the northern part of the anticyclone $\sim 30^{\circ} \mathrm{N}$ (Fig. S2) which is enhanced (positive anomalies) in the Asia-10 simulations (Fig. S4a-d). The spatial distribution of ozone anomalies (Fig. S4e-h) indicate that the response to emission reductions generates negative anomalies of ozone in the southern part of anticyclone (15$25^{\circ} \mathrm{N} ; 60-120^{\circ} \mathrm{E}$ ) (may be due to cross tropopause of monsoon air), while ozone anomalies are positive in the northern part of the anticyclone (which may be associated with stratospheric intrusions). The ozone variability near the tropopause is generally driven by the strong mixing of tropospheric and stratospheric air masses.

In Fig. 8i-1, negative values of ozone anomalies extending from the surface to $\sim 180 \mathrm{hPa}$ may likely be related to the vertical extent of transport and associated outflow. A plume of high values of $\mathrm{CO}(\sim 95 \mathrm{ppb})$ and PAN $(\sim 260 \mathrm{ppt})$ (Fig. 7), together with relatively low amounts of ozone (70$80 \mathrm{ppb}$ ) (Fig. S2) reaching to $\sim 180 \mathrm{hPa}$ and leads to a strong gradient near the tropopause. This also indicates that the outflow of uplifted trace gases in the upper troposphere reaches to $\sim 250-180 \mathrm{hPa}$. The moderate concentrations of $\mathrm{CO}$ and PAN between 180 and $70 \mathrm{hPa}$ may also be due to the slow ascent into the lower stratosphere of these Asian pollutants (Park et al., 2008).

During the monsoon season, marine air masses containing low amounts of ozone prevail over the Asian land mass. The monsoon air mass gathers Asian boundary layer ozone precursors (and other trace gases) and are uplifted to the UTLS by the monsoon circulation. It should be noted that a decrease in emissions of $\mathrm{NO}_{x}$ and NMVOCs in the Asia-10 simulations produces lower amounts of ozone in the troposphere than in the CTRL simulation. Therefore, in the regions of eddy shedding, negative anomalies near $200-300 \mathrm{hPa}$ indicate transport of monsoon air (via eddies) towards western Africa during 1-5 July and to the western Pacific during 48 July.

\subsection{Influence of Asian emission of trace gases on ozone heating rates}

Ozone is a dominant contributor to radiative heating in the tropical lower stratosphere, impacting the local heating budget and non-local forcing of the troposphere below (Gilford and Solomon, 2017). We estimate changes in ozone heating rates caused by a $10 \%$ decrease in Asian NMVOCs and $\mathrm{NO}_{x}$ emissions. Figure $9 \mathrm{a}-\mathrm{d}$, show anomalies of ozone heating rates on 1-8 July (plotted on alternate days), indicating a reduction in ozone heating rates in response to a decrease in Asian NMVOCs and $\mathrm{NO}_{x}$ emissions, coincident with the region of convective transport (see also Fig. S5). In the upper troposphere (300-180 $\mathrm{hPa})$, the negative anomalies in ozone heating rates vary between -0.001 and $-0.0045 \mathrm{~K} \mathrm{day}^{-1}$. Interestingly, reduced Asian emissions (NMVOCs and $\mathrm{NO}_{x}$ ), lead to a reduction in ozone, which leads to a reduction in ozone heating rates $\left(-0.001\right.$ to $\left.-0.003 \mathrm{~K} \mathrm{day}^{-1}\right)$ in the region of eddy shedding over western Africa (1-5 July) and the western Pacific (4-8 July). The ozone poor Asian air mass trapped within eddies has reduced the heating over western Africa and the western Pacific. Influence of Asian $\mathrm{NO}_{x}$ emissions on ozone heating rates (mean for June-September $\sim 0.0001-0.0012 \mathrm{~K} \mathrm{day}^{-1}$ for $38 \%$ increase over India) in the upper troposphere (300-200 hPa) have been reported in the past (Roy et al., 2017). Near the tropopause ozone heating rates are positive $\left(0.001-0.005 \mathrm{~K} \mathrm{day}^{-1}\right)$ except in the region of cross-tropopause transport (marked in Fig. 8i-1). The positive anomalies of ozone heating rates are associated with positive anomalies of ozone near the tropopause. The ECMWF 
data set for 44 years (1958-2001) shows an interannual amplitude of the ozone heating rate $\pm 0.00025 \mathrm{~K} \mathrm{day}^{-1}$ near the tropopause over $30^{\circ} \mathrm{S}-30^{\circ} \mathrm{N}$ (Wang et al., 2008).

\section{Summary and discussion}

In this study, we showed evidence of eddy shedding from the ASM anticyclone to both its eastern and western edges, during 1-8 July 2003 based on MIPAS satellite observations and ERA-Interim reanalysis data as well as the associated transport patterns of trace gases from the ASM region to remote regions. The transport diagnostic based on ERAInterim data shows that eddy shedding events are associated with RWB in the subtropical westerly jet. The RWB feature moves eastward in the subtropical westerly jet. Initially, during 1-5 July 2003, RWB occurs in the western part of the anticyclone and then sheds over western Africa $\left(20-30^{\circ} \mathrm{N}\right.$, $0-30^{\circ}$ E). Later, during 5-8 July 2003, RWB moves to the eastern part of the anticyclone and sheds an eddy over the western Pacific $\left(20-30^{\circ} \mathrm{N} ; 120-150^{\circ} \mathrm{E}\right)$. Analysis of ERAInterim PV data for the last two decades (1995-2016) shows that the occurrence frequency of eddy shedding from the ASM anticyclone over western Africa is $\sim 68 \%$ and $\sim 25 \%$ over the western Pacific. In the UTLS (300-100 hPa), eddies (PV <2 PVU) over western Africa and the western Pacific shows the highest correlations with the $\mathrm{PV}$ in the anticyclone after accounting for 3-4 days or 5-6 days of lag. This indicates that the anticyclone sheds eddies with a transport duration of typically 3 to 4 days to western Africa and 5-6 days to the western Pacific.

We employed the chemistry climate model ECHAM5HAMMOZ to investigate the transport of Asian boundary layer trace gases ( $\mathrm{CO}$, ozone and PAN) into the monsoon anticyclone and the associated eddies. The model simulations show that Asian trace gases transported into the monsoon anticyclone are further carried away horizontally towards western Africa and the western Pacific by eddies which detach from the anticyclone. These eddies protrude down to $\sim 200 \mathrm{hPa}$ over western Africa and $\sim 500 \mathrm{hPa}$ over the western Pacific. They redistribute Asian trace gases downward into the troposphere over these regions. Moreover, part of this air mass is also transported upward into the lower stratosphere. A higher frequency of eddy shedding over western Africa (68\%) during the last two decades (1995-2016) indicates a greater influence of Asian trace gases on the UTLS over western Africa than the western Pacific over this period.

We evaluated the impact of Asian $\mathrm{NO}_{x}$ and NMVOCs emissions on ozone and PAN in the regions of the ASM anticyclone and the associated eddies. The model sensitivity simulations for a $10 \%$ reduction in Asian emissions of NMVOCs and $\mathrm{NO}_{x}$ indicate significant reduction $(\sim 2-$ $-10 \%)$ in the concentration of PAN in the UTLS (300$80 \mathrm{hPa}$ ) over western Africa and the western Pacific. The vertical distribution of anomalies of PAN shows negative val- ues along the transport pathways, i.e. rising from the Asian region $\left(80-120^{\circ} \mathrm{E}\right)$ into the upper troposphere, and in both westward and eastward transport towards the region of eddy shedding. Tropospheric ozone $(1000-180 \mathrm{hPa})$ shows a decrease of up to $-4.5 \%$ in response to a $10 \%$ decrease in Asian emissions of NMVOCs and $\mathrm{NO}_{x}$, while positive ozone anomalies (up to $8 \%$ ) are seen near the tropopause. In general, negative ozone anomalies in response to $10 \%$ reduction of $\mathrm{NO}_{x}$ and NMVOCs in the region of convective transport are seen in Fig. 8i-1. However, positive anomalies of ozone are observed near the tropopause (except in the region of cross-tropopause transport), which may be due to reduction in the efficiency of ozone loss induced by lower concentrations of $\mathrm{NO}_{x}$ and $\mathrm{OH}$ in the Asia-10 simulations and changes in dynamics due to emission changes, e.g. stratospheric intrusions and lightning. The mixing of tropospheric and stratospheric air masses near the tropopause generates ozone variability. However, such an analysis is beyond the scope of the paper.

Our analysis indicates that transport of Asian trace gases from the anticyclone to western Africa and the western Pacific via eddies causes a change in the chemical composition of the UTLS and may therefore impact the radiative balance of the UTLS. We also estimate that a $10 \%$ reduction in Asian NMVOCs and $\mathrm{NO}_{x}$ emissions leads to a decrease in ozone heating rates of 0.001 to $0.004 \mathrm{~K} \mathrm{day}^{-1}$ in the region of transport into the troposphere and an increase of 0.001 to $0.005 \mathrm{~K} \mathrm{day}^{-1}$ near the tropopause and lower stratosphere $(180-50 \mathrm{hPa})$ over Asia $\left(20-150^{\circ} \mathrm{E} ; 20-40^{\circ} \mathrm{N}\right)$. Previous studies showed that ozone changes in the lower stratosphere have the largest impact on the ozone radiative forcing (Riese et al., 2012). Interestingly, in the upper-troposphere $(200-300 \mathrm{hPa})$ negative anomalies of ozone heating rates $(\sim$ $0.001-0.003 \mathrm{~K} \mathrm{day}^{-1}$ ) are seen in the region of eddy shedding over western Africa and the western Pacific. Thus, transport of Asian air masses via eddies eventually alters the heating rates in the UTLS in the regions of eddy shedding and may thus affect radiative forcing and local temperature. However, such questions are beyond the scope of this study. It should be noted that the distributions of MIPAS concentration fields look different from those of ERA-Interim and ECHAM5-HAMMOZ. These differences may be due to a number of reasons, e.g. different grid sizes of MIPAS, ERAInterim and model data, binning of MIPAS data for 2 days to accommodate better spatial coverage, uncertainties in the model emission inventory, and retrieval errors in the satellite data. The ozone heating rates estimated from the model simulations will vary accordingly. Notwithstanding, we suggest further scrutiny of long-range transport of Asian trace gases via eddies shedding from the anticyclone and its impact on ozone heating rates in the respective regions.

Data availability. MIPAS data products were obtained from the password-protected "Access to MIPAS/Envisat data" website (http: 
//share.lsdf.kit.edu/imk/asf/sat/mipas-export/, last access: 9 August 2018) at the Karlsruhe Institute of Technology. ERA-Interim reanalysis data were obtained from the European Centre for MediumRange Weather Forecasts (ECMWF) from http://apps.ecmwf.int/ datasets/data/interim-full-daily/levtype=pl/ (ECMWF, 2018).

Supplement. The supplement related to this article is available online at: https://doi.org/10.5194/acp-18-11493-2018-supplement.

Author contributions. SF designed the study and wrote the paper, $\mathrm{CR}, \mathrm{RC}$ and $\mathrm{KRK}$ conducted the analysis from ERA-Interim data and model simulations. AR provided the analysis of ozone heating rates; CES conducted the analysis of the MIPAS data. RM contributed to the study design and writing of the paper. RK helped to write and improve the manuscript overall.

Competing interests. The authors declare that they have no conflict of interest.

Acknowledgements. Suvarna Fadnavis and Chaitri Roy acknowledge Ravi Nanjundiah, Director of IITM, with gratitude for his encouragement during the course of this study. We are grateful to Bärbel Vogel for helpful discussions. This work was partly funded by the European Community's Seventh Framework Programme (FP7/2007-2013) as part of the StratoClim project (grant agreement no. 603557). We thank the European Centre for Medium-Range Weather Forecasts (ECMWF) for providing meteorological data sets. The authors are also thankful to Bernd Funke, Michael Kiefer and Gabriele Stiller, Karlsruhe Institute of Technology, Germany, for providing MIPAS data and for helpful discussions. We thank the anonymous reviewers for their valuable suggestions.

Edited by: Martin Dameris

Reviewed by: three anonymous referees

\section{References}

Bourassa, A. E., Robock, A., Randel, W. J., Deshler, T., Rieger, L. A., Lloyd, N. D., Llewellyn, E. J., and Degenstein, D. A.: Large volcanic aerosol load in the stratosphere linked to Asian monsoon transport, Science, 336, 78-81, https://doi.org/10.1126/science.1219371, 2012.

Edwards, J. M. and Slingo, A.: Studies with a flexible new radiation code. I: Choosing a configuration for a largescale model, Q. J. Roy. Meteor. Soc., 122, 689-719, https://doi.org/10.1256/smsqj.53106, 1996.

European Centre for Medium-Range Weather Forecasts (ECMWF): ECMWF, ERA Interim, Daily, available at: http://apps.ecmwf. int/datasets/data/interim-full-daily/levtype $=\mathrm{pl} /$, last access: 9 August 2018.

Fadnavis, S. and Chattopadhyay, R.: Linkages of subtropical stratospheric intraseasonal intrusions with Indian sum- mer monsoon deficit rainfall, J. Climate, 30, 5083-5095, https://doi.org/10.1175/JCLI-D-16-0463.1, 2017.

Fadnavis, S., Semeniuk, K., Pozzoli, L., Schultz, M. G., Ghude, S. D., Das, S., and Kakatkar, R.: Transport of aerosols into the UTLS and their impact on the Asian monsoon region as seen in a global model simulation, Atmos. Chem. Phys., 13, 8771-8786, https://doi.org/10.5194/acp-13-8771-2013, 2013.

Fadnavis, S., Schultz, M. G., Semeniuk, K., Mahajan, A. S., Pozzoli, L., Sonbawne, S., Ghude, S. D., Kiefer, M., and Eckert, E.: Trends in peroxyacetyl nitrate (PAN) in the upper troposphere and lower stratosphere over southern Asia during the summer monsoon season: regional impacts, Atmos. Chem. Phys., 14, 12725-12743, https://doi.org/10.5194/acp-14-127252014, 2014.

Fadnavis, S., Semeniuk, K., Schultz, M. G., Kiefer, M., Mahajan, A., Pozzoli, L., and Sonbawane, S.: Transport pathways of peroxyacetyl nitrate in the upper troposphere and lower stratosphere from different monsoon systems during the summer monsoon season, Atmos. Chem. Phys., 15, 11477-11499, https://doi.org/10.5194/acp-15-11477-2015, 2015.

Fischer, H., Birk, M., Blom, C., Carli, B., Carlotti, M., von Clarmann, T., Delbouille, L., Dudhia, A., Ehhalt, D., Endemann, M., Flaud, J. M., Gessner, R., Kleinert, A., Koopman, R., Langen, J., López-Puertas, M., Mosner, P., Nett, H., Oelhaf, H., Perron, G., Remedios, J., Ridolfi, M., Stiller, G., and Zander, R.: MIPAS: an instrument for atmospheric and climate research, Atmos. Chem. Phys., 8, 2151-2188, https://doi.org/10.5194/acp-8-21512008, 2008.

Funke, B., López-Puertas, M., García-Comas, M., Stiller, G. P., von Clarmann, T., Höpfner, M., Glatthor, N., Grabowski, U., Kellmann, S., and Linden, A.: Carbon monoxide distributions from the upper troposphere to the mesosphere inferred from $4.7 \mu \mathrm{m}$ non-local thermal equilibrium emissions measured by MIPAS on Envisat, Atmos. Chem. Phys., 9, 2387-2411, https://doi.org/10.5194/acp-9-2387-2009, 2009.

Garny, H. and Randel, W. J.: Transport pathways from the Asian monsoon anticyclone to the stratosphere, Atmos. Chem. Phys., 16, 2703-2718, https://doi.org/10.5194/acp-16-27032016, 2016.

Ghude, S. D., Kulkarni, S. H., Jena, C., Pfister, G. G., Beig, G., Fadnavis, S., and van Der, R. J.: Application of satellite observations for identifying regions of dominant sources of nitrogen oxides over the indian subcontinent, J. Geophys. Res.-Atmos., 118, 1075-1089, https://doi.org/10.1029/2012JD017811, 2013.

Gilford, D. M. and Solomon, S.: Radiative effects of stratospheric seasonal cycles in the tropical upper troposphere and lower stratosphere, J. Climate, 30, 2769-2783, https://doi.org/10.1175/JCLI-D-16-0633.1, 2017.

Glatthor, N., von Clarmann, T., Fischer, H., Funke, B., Grabowski, U., Höpfner, M., Kellmann, S., Kiefer, M., Linden, A., Milz, M., Steck, T., and Stiller, G. P.: Global peroxyacetyl nitrate (PAN) retrieval in the upper troposphere from limb emission spectra of the Michelson Interferometer for Passive Atmospheric Sounding (MIPAS), Atmos. Chem. Phys., 7, 2775-2787, https://doi.org/10.5194/acp-7-2775-2007, 2007.

Horowitz, L. W., Walters, S., Mauzerall, D. L., Emmons, L. K., Rasch, P. J., Granier, C., Tie, X., Lamarque, J.-F., Schultz, M. G., Tyndall, G. S., Orlando, J. J., and Brasseur, G. P.: A global simulation of tropospheric ozone and related tracers: Description 
and evaluation of MOZART, version 2, J. Geophys. Res.-Atmos., 108, 4784, https://doi.org/10.1029/2002JD002853, 2003.

Hsu, C. J. and Plumb, R. A.: Nonaxisymmetric thermally driven circulations and upper-tropospheric monsoon dynamics, J. Atmos. Sci., 57, 1255-1276, https://doi.org/10.1175/15200469(2000)057<1255:NTDCAU>2.0.CO;2, 2000.

Li, M., Zhang, Q., Streets, D. G., He, K. B., Cheng, Y. F., Emmons, L. K., Huo, H., Kang, S. C., Lu, Z., Shao, M., Su, H., $\mathrm{Yu}, \mathrm{X}$., and Zhang, Y.: Mapping Asian anthropogenic emissions of non-methane volatile organic compounds to multiple chemical mechanisms, Atmos. Chem. Phys., 14, 5617-5638, https://doi.org/10.5194/acp-14-5617-2014, 2014.

Liang, Q., Jaeglé, L., Jaffe, D. A., Weiss-Penzias, P., Heckman, A., and Snow, J. A.: Long-range transport of Asian pollution to the northeast Pacific: Seasonal variations and transport pathways of carbon monoxide, J. Geophys. Res.-Atmos., 109, 1-16, https://doi.org/10.1029/2003JD004402, 2004.

Naik, V., Mauzerall, D., Horowitz, L., Schwarzkopf, M. D., Ramaswamy, V., and Oppenheimer, M.: Net radiative forcing due to changes in regional emissions of tropospheric ozone precursors, J. Geophys. Res., 110, D24306, https://doi.org/10.1029/2005JD00590, 2005.

Nützel, M., Dameris, M., and Garny, H.: Movement, drivers and bimodality of the South Asian High, Atmos. Chem. Phys., 16, 14755-14774, https://doi.org/10.5194/acp-16-14755-2016, 2016.

Ohara, T., Akimoto, H., Kurokawa, J., Horii, N., Yamaji, K., Yan, X., and Hayasaka, T.: An Asian emission inventory of anthropogenic emission sources for the period 1980-2020, Atmos. Chem. Phys., 7, 4419-4444, https://doi.org/10.5194/acp-7-44192007, 2007.

Park, M., Randel, W. J., Emmons, L. K., Bernath, P. F., Walker, K. A., and Boone, C. D.: Chemical isolation in the Asian monsoon anticyclone observed in Atmospheric Chemistry Experiment (ACE-FTS) data, Atmos. Chem. Phys., 8, 757-764, https://doi.org/10.5194/acp-8-757-2008, 2008.

Payne, V. H., Fischer, E. V., Worden, J. R., Jiang, Z., Zhu, L., Kurosu, T. P., and Kulawik, S. S.: Spatial variability in tropospheric peroxyacetyl nitrate in the tropics from infrared satellite observations in 2005 and 2006, Atmos. Chem. Phys., 17, 63416351, https://doi.org/10.5194/acp-17-6341-2017, 2017.

Ploeger, F., Gottschling, C., Griessbach, S., Grooß, J.-U., Guenther, G., Konopka, P., Müller, R., Riese, M., Stroh, F., Tao, M., Ungermann, J., Vogel, B., and von Hobe, M.: A potential vorticitybased determination of the transport barrier in the Asian summer monsoon anticyclone, Atmos. Chem. Phys., 15, 13145-13159, https://doi.org/10.5194/acp-15-13145-2015, 2015.

Ploeger, F., Konopka, P., Walker, K., and Riese, M.: Quantifying pollution transport from the Asian monsoon anticyclone into the lower stratosphere, Atmos. Chem. Phys., 17, 7055-7066, https://doi.org/10.5194/acp-17-7055-2017, 2017.

Popovic, J. M. and Plumb, R. A.: Eddy Shedding from the Upper-Tropospheric Asian Monsoon Anticyclone, J. Atmos. Sci., 58, 93-104, https://doi.org/10.1175/15200469(2001)058<0093:ESFTUT>2.0.CO;2, 2001.

Pozzoli, L., Janssens-Maenhout, G., Diehl, T., Bey, I., Schultz, M. G., Feichter, J., Vignati, E., and Dentener, F.: Reanalysis of tropospheric sulfate aerosol and ozone for the period 1980-2005 using the aerosol-chemistry-climate model
ECHAM5-HAMMOZ, Atmos. Chem. Phys., 11, 9563-9594, https://doi.org/10.5194/acp-11-9563-2011, 2011.

Randel, W. J., Park, M., Emmons, L., Kinnison, D., Bernath, P., Walker, K. A., Boone, C., and Pumphrey, H.: Asian monsoon transport of trace gases to the stratosphere, Science, 328, 611613, 10.1126/science.1182274, 2010.

Rap, A., Richards, N. A. D., Forster, P. M., Monks, S., Arnold, S. R., and Chipperfield, M.: Satellite constraint on the tropospheric ozone radiative effect, Geophys. Res. Lett., 42, 50745081, https://doi.org/10.1002/2015GL064037, 2015.

Riese, M., Ploeger, F., Rap, A., Vogel, B., Konopka, P., Dameris, M., and Forster, P.: Impact of uncertainties in atmospheric mixing on simulated UTLS composition and related radiative effects, J. Geophys. Res., 117, D16305, https://doi.org/10.1029/2012JD017751, 2012.

Roeckner, E., Bauml, G., Bonaventura, L., Brokopf, R., Esch, M., Giorgetta, M., Hagemann, S., Kirchner, I., Kornblueh, L., Manzini, E., Rhodin, A., Schlese, U., Schulzweida, U., and Tompkins, A.: The atmospheric general circulation model ECHAM5: Part 1, Tech. Rep. 349, Max Planck Institute for Meteorology, Hamburg, 2003.

Roy, C., Fadnavis, S., Müller, R., Ayantika, D. C., Ploeger, F., and Rap, A.: Influence of enhanced Asian $\mathrm{NO}_{x}$ emissions on ozone in the upper troposphere and lower stratosphere in chemistryclimate model simulations, Atmos. Chem. Phys., 17, 1297-1311, https://doi.org/10.5194/acp-17-1297-2017, 2017.

Santee, M. L., Manney, G. L., Livesey, N. J., Schwartz, M. J., Neu, J. L., and Read, W. G.: A comprehensive overview of the climatological composition of the Asian summer monsoon anticyclone based on 10 years of Aura Microwave Limb Sounder measurements, J. Geophys. Res.-Atmos., 122, 54915514, https://doi.org/10.1002/2016JD026408, 2017.

Schneider, P. and van Der A, R. J.: A global single-sensor analysis of 2002-2011 tropospheric nitrogen dioxide trends observed from space, J. Geophys. Res.-Atmos., 117, 1-17, https://doi.org/10.1029/2012JD017571, 2012.

Stier, P., Feichter, J., Kinne, S., Kloster, S., Vignati, E., Wilson, J., Ganzeveld, L., Tegen, I., Werner, M., Balkanski, Y., Schulz, M., Boucher, O., Minikin, A., and Petzold, A.: The aerosol-climate model ECHAM5-HAM, Atmos. Chem. Phys., 5, 1125-1156, https://doi.org/10.5194/acp-5-1125-2005, 2005.

Streets, D. G., Yarber, K. F., Woo, J.-H., and Carmichael, G. R.: Biomass burning in Asia: Annual and seasonal estimates and atmospheric emissions, Global Biogeochem. Cy., 17, 1099, https://doi.org/10.1029/2003GB002040, 2003.

Strode, S. A. and Pawson, S.: Detection of carbon monoxide trends in the presence of interannual variability, J. Geophys. Res.-Atmos., 118, 12257-12273, https://doi.org/10.1002/2013JD020258, 2013.

Strong, C. and Magnusdottir, G.: Tropospheric Rossby wave breaking and the NAO/NAM, J. Atmos. Sci., 65, 2861-2876, https://doi.org/10.1175/2008JAS2632.1, 2008.

Tereszchuk, K. A., Moore, D. P., Harrison, J. J., Boone, C. D., Park, M., Remedios, J. J., Randel, W. J., and Bernath, P. F.: Observations of peroxyacetyl nitrate (PAN) in the upper troposphere by the Atmospheric Chemistry Experiment-Fourier Transform Spectrometer (ACE-FTS), Atmos. Chem. Phys., 13, 5601-5613, https://doi.org/10.5194/acp-13-5601-2013, 2013. 
Tie, X., Zhang, R., Brasseur, G., and Lei, W.: Global $\mathrm{NO}_{x}$ Production by Lightning, J. Atmos. Chem., 43, 61-74, https://doi.org/10.1023/A:1016145719608, 2002.

Ungermann, J., Ern, M., Kaufmann, M., Müller, R., Spang, R., Ploeger, F., Vogel, B., and Riese, M.: Observations of PAN and its confinement in the Asian summer monsoon anticyclone in high spatial resolution, Atmos. Chem. Phys., 16, 8389-8403, https://doi.org/10.5194/acp-16-8389-2016, 2016.

Uppala, S. M., Kållberg, P. W., Simmons, A. J., Andrae, U., da Costa Bechtold, V., Fiorino, M., Gibson, J. K., Haseler, J., Hernandez, A., Kelly, G. A., Li, X., Onogi, K., Saarinen, S., Sokka, N., Allan, R. P., Andersson, E., Arpe, K., Balmaseda, M. A., Beljaars, A. C. M., van de Berg, L., Bidlot, J., Bormann, N., Caires, S., Chevallier, F., Dethof, A., Dragosavac, M., Fisher, M., Fuentes, M., Hagemann, S., Hólm, E., Hoskins, B. J., Isaksen, L., Janssen, P. A. E. M., Jenne, R., McNally, A. P., Mahfouf, J. F., Morcrette, J. J., Rayner, N. A., Saunders, R. W., Simon, P., Sterl, A., Trenberth, K. E., Untch, A., Vasiljevic, D., Viterbo, P., and Woollen, J.: The ERA-40 re-analysis, Q. J. Roy. Meteor. Soc., 131, 2961-3012, https://doi.org/10.1256/qj.04.176, 2005.

van der Werf, G. R., Randerson, J. T., Giglio, L., Collatz, G. J., Kasibhatla, P. S., and Arellano Jr., A. F.: Interannual variability in global biomass burning emissions from 1997 to 2004, Atmos. Chem. Phys., 6, 3423-3441, https://doi.org/10.5194/acp-6-34232006, 2006.

Verstraeten, W. W., Neu, J. L., Williams, J. E., Bowman, K. W., Worden, J. R., and Boersma, K. F.: Rapid increases in tropospheric ozone production and export from China, Nat. Geosci., 8, 690-695, https://doi.org/10.1038/ngeo2493, 2015.

Vogel, B., Günther, G., Müller, R., Grooß, J.-U., Hoor, P., Krämer, M., Müller, S., Zahn, A., and Riese, M.: Fast transport from Southeast Asia boundary layer sources to northern Europe: rapid uplift in typhoons and eastward eddy shedding of the Asian monsoon anticyclone, Atmos. Chem. Phys., 14, 12745-12762, https://doi.org/10.5194/acp-14-12745-2014, 2014.
Vogel, B., Günther, G., Müller, R., Grooß, J.-U., Afchine, A., Bozem, H., Hoor, P., Krämer, M., Müller, S., Riese, M., Rolf, C., Spelten, N., Stiller, G. P., Ungermann, J., and Zahn, A.: Longrange transport pathways of tropospheric source gases originating in Asia into the northern lower stratosphere during the Asian monsoon season 2012, Atmos. Chem. Phys., 16, 15301-15325, https://doi.org/10.5194/acp-16-15301-2016, 2016.

Vogel, B., Müller, R., Günther, G., Spang, R., Hanumanthu, S., Li, D., Riese, M., and Stiller, G. P.: Lagrangian simulations of the transport of young air masses to the top of the Asian monsoon anticyclone and into the tropical pipe, Atmos. Chem. Phys. Discuss., https://doi.org/10.5194/acp-2018-724, in review, 2018.

von Clarmann, T., De Clercq, C., Ridolfi, M., Höpfner, M., and Lambert, J.-C.: The horizontal resolution of MIPAS, Atmos. Meas. Tech., 2, 47-54, https://doi.org/10.5194/amt-2-47-2009, 2009.

Wang, W.-G., Yuan, M., Wang, H.-Y., Sun, J.-H., Xie, Y.-Q., Fan, W.-X., and Chen, X.-M.: A Study of Ozone Amount in the Transition Layer Between Troposphere and Stratosphere and Its Heating Rate, Chinese J. Geophys.-Ch., 51, 916-930, https://doi.org/10.1002/cjg2.1287, 2008.

Wayne, R. P.: Chemistry of atmospheres, 3rd Edn., Oxford science publications, Clarendon Press, Oxford, 337 pp., ISBN: 0 $19850375 X, 2000$.

Zhang, Q., Wu, G., and Qian, Y.: The Bimodality of the $100 \mathrm{hPa}$ South Asia High and its Relationship to the Climate Anomaly over East Asia in summer, J. Meteorol. Soc. Jpn., 80, 733-744, https://doi.org/10.2151/jmsj.80.733, 2002.

Zhao, C., Wang, Y., Choi, Y., and Zeng, T.: Summertime impact of convective transport and lightning NOx production over North America: modeling dependence on meteorological simulations, Atmos. Chem. Phys., 9, 4315-4327, https://doi.org/10.5194/acp9-4315-2009, 2009 